Milena Jovanović-Kranjec ${ }^{1}$

University of Kragujevac, Faculty of Economics

Danijela Despotovic ${ }^{2}$

University of Kragujevac, Faculty of Economics
SCIENTIFIC REVIEW ARTICLE

doi:10.5937/ekonomika1801123J

Received December, 18, 2018

Accepted: February, 19, 2018

\title{
IMPORTANCE OF COOPERATION BETWEEN UNIVERSITIES AND INDUSTRY AS A FACTOR OF ECONOMIC AND SOCIAL DEVELOPMENT OF THE REPUBLIC OF SERBIA
}

\begin{abstract}
In a very dynamic social environment, which includes a whole range of political, economic, cultural, and social changes, one can notice that, "today", education is facing new requirements, which primarily result from the needs of the economy and production. The role of university is not only to create and transfer knowledge, but to integrate with the economy for future economic progress and social development. The subject of this paper is to analyze past and current cooperation between university and industry in the Republic of Serbia, based on official national and international statistics. Given that education in a society is assumption of dynamic economic and social development, the aim of this paper is to make a comprehensive analysis of the importance of cooperation between university and industry, and point to the need for continuous and institutionalized cooperation between university and industry, as a key factor for the future strategy of economic and social development of the Republic of Serbia.
\end{abstract}

Key words: university, industry, higher education, economic development, human capital

JELClassification: I25, I28, H52, Z13

\section{ЗНАЧАЈ САРАДЊЕ УНИВЕРЗИТЕТА И ПРИВРЕДЕ КАО ФАКТОРА ПРИВРЕДНОГ И СОЦИЈАЛНОГ РАЗВОЈА РЕПУБЛИКЕ СРБИЈЕ}

\begin{abstract}
Апстракт
Из врло динамичног друштвеног окружења, које подразумева читав низ политичких, економских, културолошких и сочијалних промена, можемо да приметимо да се “данас" пред образовање постављају нови захтеви, који примарно произилазе из потреба привреде и производње. Улога Универзитета није више само да ствара и преноси знање, већ да се Универзитет интегрише са привредом у ииљу будућег привредног напредка и соиијалног развоја. Предмет овог рада је анализа досадашье и тренутне сарадње Универзитета и привреде у Републиии Србији, на основу званичне домаће и међу-
\end{abstract}

\footnotetext{
${ }^{1}$ mkranjec@kg.ac.rs

2ddespotovic@kg.ac.rs
} 
народне статистике. С обзиром да је образовање једног друштва предпоставка динамичког привредног и сочијалног развоја, ици овог рада је да се кроз свеобухватну анализу значаја који сарадња Унивезитета и привреде има укаже на неопходност континуиране и институционализоване сарадње Универзитета и привреде као кључног фактора будуће стратегије привредног и соиијалног развоја Републике Србије.

Кључне речи: Универзитет, привреда, високо образовање, привредни развој, људски капитал.

\section{Introduction}

"Learning used to be a luxury for the elite, now this is a national need, the need for the broad masses,

in the true sense of the word.

He who does not understand these processes, does not understand the tendency of the time, and falls short.

He who, contrary to this understands these changes, for him the future has already begun".

Bilandžija, B. (Bilandžija, 2010 , p.240)

Education system of a society is a key determinant of its development. At the same time, education system is inseparable from economic, commercial, political, cultural, and demographic development of the society in which it develops.

The importance that education plays in the growth and development of the national economy has long been accepted, and it no longer strikes the attention of teachers, experts in the field of pedagogy, adult education, sociology, but a growing number of economists and experts in other fields of science believe that development of a society is directly related to investment in education (or as economists point out, in human capital).

Economists usually speak of "knowledge-based economy" or "knowledge-driven economy". Distinction should be made between the notion of knowledge economy, where knowledge is the product developed through intellectual effort (in the broad sense of the term product) and the concept of knowledge-based economy, where knowledge is classified into production factors (Ješić, 2015, p.25). The terms are, regardless of different interpretations of knowledge, very connected.

It is the concept more than a decade long, and in our country is still used only rhetorically, which actually reflects the attitude we have as a society toward education. If we keep repeating for more than one decade a platitude that knowledge is a capital and an important economic resource, but do nothing to take advantage of knowledge that we invest in, or at least try to create a knowledge-based economy, then we are a very irresponsible country in social terms. This is one of the reasons why investment in education is seen as a cost. When we change our perception of importance of education in a society, we will realize that investing in education is an investment for the future. It is even more irresponsible of us if we know that "the underlying macroeconomic assumptions about economic growth and development of competitiveness of an 
economy are based on constant improvement of labor force skills as the basic factor of production. Human capital, especially intellectual capital, is one of the main factors of competitiveness of companies and the economy" (Jovancai, Tošović-Stevanović, 2013, p.87).

The role of university is not only to create and transfer knowledge, but to integrate with the economy for future economic progress. This does not mean that its primary role of transferring knowledge has been lost, but the contrary, that university, driven by the spirit of times in which it survives, only got other, new roles. The sooner we realize that "economy is the one that sets the criteria for classification of professional staff, while education offers an answer to the given requirements and needs", the better it will be for our society (Gajić, Lungulov, 2012, p.4). How important is cooperation between university and industry is seen in the fact that, today, most developed countries in social terms, or most competitive countries in economic terms, are "knowledge-based economies". This does not mean that these economies use the latest knowledge; the context is much broader, referring to economies that, in addition to previously said, place emphasis on networking and cooperation between various public institutions, businesses, students, and university.

Given that education is a society's assumption of dynamic economic and social development, the aim of this paper is to point out the necessity of cooperation between university and industry, as a key factor for the future strategy of economic and social development of the Republic of Serbia.

\section{Key indicators of the economic situation of the Republic of Serbia. Where are we?}

If we look, on the one hand, at the key determinants and current and official data on economic and social development of our country, i.e. level of gross domestic product, level of investment, level of competitiveness of the Serbian economy, and level of inflation and employment, we can conclude that economic and social conditions are not favorable in our country and that something should be changed. In such situations, the help of resources that we have as a country should be sought. Knowledge is certainly an economic resource. The truth, underused, but still a resource.

Even greater paradox is that we listen to decades-long praise of the most educated professionals we educate, experts in the fields of economics, industry, agriculture, tourism, management, a large number of highly educated young people who go to other countries. On the one hand, there is a discouraging "diagnosis" of our society, and, on the other, there is a resource in the form of knowledge that is exported or not used, resulting in economic and social situation that is more than worrying. What is it that has stuck Serbia for decades, and does not allow it to move and change what it can with resources available?

Data that is not encouraging, but should certainly initiate not only thinking but also action, tells us the following.

One of the most important economic indicators through which one monitors the development of a country is gross domestic product (GDP), which is the total value of all 
goods produced and services rendered in a country during one year. This is the measure by which we monitor total income and expenditure of the economy. Gross domestic product (GDP) per capita in Serbia from 2006 to 2014 ranged from 4896.82 US dollars in 2006 to 5670.71 US dollars in 2013. Judging by the World Bank data, gross domestic product in Serbia was last recorded in 2015, and amounted to 5659.33 dollars, slightly lower compared to 2014, when it stood at 5593.06 US dollars.( World Bank data, gdpper-capita). According to the latest Chamber of Commerce of the Republic of Serbia data of November 2015, "real GDP growth in the second quarter of 2016 amounted to 2\%, driven by strong growth in the construction sector and manufacturing industry, as well as higher private consumption. Current estimates are that the third quarter grew at a higher level, of $2.5 \%$, due to an increase in investment activity and exports". This is still low level of GDP of the Republic of Serbia.

Based on the data in the 2016 World Economic Forum report, the Republic of Serbia is ranked $90^{\text {th }}$ among 138 countries by the value of the Global Competitiveness Index (GCI) of 3.97. As the Global Competitiveness Index is measured by the average of a large number of indicators, looking individually by the criteria for assessing competitiveness, the Republic of Serbia is $53^{\text {rd }}$ in the world by health care and primary education, while, according to higher education and training, it is $69^{\text {th }}$, and $74^{\text {th }}$ by infrastructure (Social Inclusion and Poverty Reduction Unit). Place that one country occupies in the list is very important, because it tells us about the overall competitiveness of its economy, on the basis of which productivity of the national economy is determined and its ability to achieve medium-term economic growth. The Republic of Serbia is in a worse position compared to other countries in the region, with the exception of Bosnia and Herzegovina. The World Economic Forum ranks the Republic of Serbia in the group of "emerging and developing European economies". As a country, we lag behind both EU countries and countries in the region by economic and social development.

Unemployment rate is one of the most important indicators of the state of a society. Based on the latest data of the Statistical Office of the Republic of Serbia, unemployment rate for the total population (without Kosovo and Metohija) for the first quarter of 2016 was $19 \%$, while unemployment rate for working-age population of 15-64 years also for the first quarter of 2016 amounted to $19.7 \%$ (Statistical Office of the Republic of SerbiaCurrent indicators-unemployment data). These figures warn and are extremely worrying if one takes into account that the "tolerable unemployment rate is between hypothetical zero percent and $5 \%$. This means that the majority of the working-age population has a job that provides at least the minimum conditions for their existence. Unemployment rate at the level between 5\% and 10\% is alarming. High unemployment, of over 10\%, already indicates a disturbance in respect of labor supply and demand on the labor market, fall in economic activity, slow process of creating new jobs, lack of competitiveness of the economy, and so on. From a sociological point of view, such a high unemployment rate indicates a potential class stratification, escalating social discontent, likelihood of extreme parareligious and parapolitical organizations, and so on. A society with an unemployment rate above $15 \%$, and especially above $20 \%$, is already a severely stratified society, antagonized and socially divided, with a prevalent sense of social injustice, where a great number of people have almost no chance to realize their right to work, or, in other words, to ensure the conditions of their own survival" (Štrbac, 2014). 
Public debt of the Republic of Serbia, which is the total amount of state obligations at a given time, was, based on the Ministry of Finance - Public Debt Administration data, on 31 October 2016 24,957,755 EUR (Ministry of Finance - Public Debt Administration, 2016).

The data also shows that the share of public debt to gross domestic product of the Republic of Serbia amounted in October 2016 to as much as $72.1 \%$. This is in comparison to $20152.6 \%$ lower, but still remains very high percentage.

Data show that, if one looks at the period back from 2010 to the present day, the share of public debt to GDP of the Republic of Serbia grew until 2016, and that it was only in 2016 that it declined by $2.6 \%$ compared to previous year.

This official statistical data makes us wonder whether and how we can use resources that we have and the experience that others have to help the country. There is a legal framework given by numerous international documents ratified and documents adopted and approved by the Government of the Republic of Serbia. One such document is the Strategy on Scientific and Technological Development of Republic of Serbia for the period 2016 to 2020. It is a strategic document, whose aim is that, within five years, science in the Republic of Serbia be based on competitive system that supports excellence in science and its relevance to the economic development, competitiveness of the economy, and development of society as a whole. The mission of such a strategy is the establishment of effective national research system, integrated into the European Research Area, which, through the development of innovation, contributes to economic growth, social and cultural progress, raising the standard of citizens and quality of life (Ministry of Education, Science, and Technological Development, Strategy on Scientific and Technological Development of the Republic of Serbia for the period 2016 to 2020). Education Development Strategy in Serbia until 2020, in part related to higher education, states that strategic objectives in higher education, which emphasize the importance of linking university and industry, are:

- Increase in quality

- Harmonization of study programs to the needs of the market

- Increase in study efficiency

- Increase in scope and availability of academic studies

- Increased mobility of students

- Modernizing academic study organization (Education Development Strategy in Serbia until 2020)

In June 2016, the Government of the Republic of Serbia presented the Program of Cooperation Between Science and Economy The purpose of this program is to encourage cooperation between private companies and public research organizations in Serbia, in order to, through joint development projects, create innovative products, services, and technology applicable on the market.

It should be noted that mere existence of a legal framework and reference to international documents and national strategies is not enough; action is needed. Today everything is verifiable and quantifiable, and mere existence of the Education Development Strategy by 2020 means nothing when the data shows that Croatia and Slovenia allocate $1 \%$ for science, EU about $1.8 \%$ on average, and the US about $3 \%$ of GDP, while the Republic of Serbia is in Europe's rear by budget allocation for science - 
only $0.3 \%$ of GDP. This data was highlighted at the roundtable discussion "Can Serbia exist without science?", organized by the Center for Democracy. How to expect science to help the economic and social recovery of a country if that country does not invest in science? There are still three years for this strategy to achieve at least the majority of the targets, and it is still at the beginning. What is the worth of the Education Development Strategy until 2020 if it is a dead letter?

\section{Faculty between theory and practice - experience in cooperation between university and industry in our country}

University professors have always used plans and programs to provide students with a sufficient level of theoretical knowledge, believing that this is what makes the students academics. "Hence, in the current social conditions, university is expected to, with other values in a society shaken (ideological, political, religious values), at least provide a clear awareness of what and who threatens them. In fact, people "turn" to university expecting it to scientifically assist them in their value systems, not only to teach them how to work" (Milošević, 2004, p.48). In recent decades, university, i.e. faculties, are under increasing "pressure" to place emphasis in students' education on practice. In addition to theory, students need sufficient practical training. This particularly highlights the first but not the only type of cooperation between university and industry. However, this cooperation has never had clear, continuous, and decisive support of democratic institutions, i.e. the state, regardless of others insisting on it and documents that emphasize the importance of that cooperation. The fact is that these documents do not highlight mechanisms to achieve it. It should be noted that cooperation has existed so far, and that there are examples of "good practice", as the society calls them, where cooperation between universities and businesses has been achieved. For example, as regards the University of Belgrade, Faculty of Mathematics has, from 2011 until today, cooperated with IT companies such as Microsoft and its Development Center in Serbia, Oracle, IBM and which together organize academic and vocational courses for students. Such training is important for students because, in addition to theoretical education, they get a chance to practically apply and test knowledge, and maybe identify one of the companies as future employer. It is also important for companies that participate in trainings and courses, because in that way they do not train all students but only those that will know how to work the way a particular company does - the company will save more time by shortening the period of habituation and costs of internal training of new employees.

University of Belgrade and the Science and Technology Park IHIS Zemun made a database named Science2Business, in order to connect academic and scientific institutions and industry.

What is certainly worth mentioning when talking about students' practice is that the University of Belgrade, Faculty of Agriculture, for the purposes of practical training of students, presentation of certain forms of teaching and scientific research, has two experimental estates: "Radmilovac" and greenhouses of the Faculty of Agriculture. Experimental estate "Radmilovac" breeds appropriate species of plants and animals 
with important varieties, breeds and genetic resources as gene banks, for carrying out scientific and research work. Within this estate, there are three centers: Center for Fruit Growing, Center for Bee-Keeping, Center for Fishery and Applied Hydrobiology. Faculty of Agriculture experimental estate "Radmilovac" organizes scientific and research work for improving the quality of studies, their development and improvement, as well as development and promotion of the profession as a whole.

Faculty of Agriculture greenhouses are a place for students' practical work, both at the undergraduate and master, as well as specialist and doctoral studies. Faculty of Agriculture of the University of Novi Sad has established cooperation between university and industry, where the IPA cross-border cooperation project team held over 50 workshops for producers.

Department of Fruit Growing, Viticulture, Horticulture and Landscape Architecture of the University of Novi Sad Faculty of Agriculture formed a cluster "Fruškogorska apple", with the aim of creating a brand, and people from agribusiness can also daily get all the necessary information and advice, and consult with the teaching staff. In addition to the Department of Fruit Growing, Viticulture, Horticulture and Landscape Architecture, the Department of Animal Husbandry has followed the same principle, and developed cooperation with individual producers in the field of poultry farming, pig farming, dairy farming, and hunting, in the form of giving advice, education, and knowledge transfer.

Cooperation between the University of Kragujevac and the industry is for now reflected in students' practice. Professional practice is defined in the curriculum and is intended for the acquisition of professional skills. The aim of this practice is to bring students closer to practical work and application of the acquired theoretical knowledge in the field for which they are educated and thus facilitate the transition from academic studies to professional work.

Of the twelve faculties of the University of Kragujevac, professional practice is being implemented in ten faculties: Faculty of Agriculture, Faculty of Engineering, Faculty of Mechanical and Civil Engineering, Faculty of Medical Sciences, Faculty of Education, Faculty of Science, Faculty of Technical Sciences, Teachers Training Faculty, Faculty of Philology and Arts, Faculty of Hotel Management and Tourism.

Center for Career Development and Student Counseling of the University of Kragujevac, in cooperation with companies, implements numerous practical programs, and a list of institutions with which they are implementing the program each year is getting longer.

Excellent initiative started by the Students' Parliament of the University of Kragujevac and the Center for Career Development and Student Counseling of the University of Kragujevac should be noted. They have over the last three years organized student summer internship in cooperation with the institutions founded by the city of Kragujevac. This is a really big effort to initiate young people studying at the University of Kragujevac and give them an opportunity to gain practice in one of the state institutions and to develop entrepreneurial competence. There are certainly more unlisted examples of cooperation between university and industry, which are always referred to as "examples of good practice".

However, when it is said that Serbia should change development policy in the field of education, it does not mean partial changing of certain segments in the field of 
education, nor referring to good practice examples by some enthusiastic group of people, institutions, or an individual. The focus should be on development policy, economic and educational policy, with emphasis on ongoing cooperation between university and industry and strong state support, which will be institutionalized and binding for all participants in the education system of the Republic of Serbia. Ways of cooperation between university and industry are numerous, as well as the benefits of such linking of theory and practice, whether it is about training programs or practical programs that aim to develop different skills that students will not get during academic studies. This is a form of linking universities and industry. With this type of connection, students are given a chance to apply their knowledge, to supplement it with new skills, to acquire entrepreneurial spirit, etc., and companies or institutions get a chance to recruit human resources.

Another way of connecting universities and industry is through work on projects: "Cooperation is carried out by connecting researchers/universities, developing knowledge and technology, and industry, seeking knowledge and technology" (Polovina, Mijušković, Kikinđanin, Milić, 2011, p.4). It also occurs in he form of consulting, creation of joint incubator centers, science parks, technology parks, and the like.

Nevertheless, it should be noted, particularly because of constant emphasis on benefits for students, universities, or the industry, that the red thread that should lead all the scientists and researchers in any scientific field, is that education must never lose its humanistic dimension, and that, even when connecting academia and industry, profits must not be in the first place, and that the main benefits for the university and the society must be long-term. The main determinants of humanistic education are derived from the understanding of general social values, such as freedom, justice, solidarity, pluralism, cooperation, development (Branković, 2014). Perhaps precisely a doubt of human intentions gives rise to doubt as to the cooperation of university and industry driven by humanistic values. In any other case, education will be bared.

\section{The importance of cooperation between university and industry}

Each level of education is very important, but when we talk about the knowledgebased economy, first we think of highly educated population. A key role in building a knowledge-based economy belongs to universities as transmitters of knowledge, the most important segment being to link universities and businesses. There is an opinion that it is a "third mission" of universities, reflected in university's participation in economic development and in building civil society and democratic values.

The concept of knowledge-based economy seeks intensive convergence of science to market needs, but also a sort of market "interference" in the world of science through the necessity of systemic application and commercialization of knowledge (Penezić, Ađelić, Ješić Andrejević-Panić, Vukadinović, 2015, p.59). This is the "today"”s necessary connection if we want economically and socially developed society.

Neverheless, it must be recognized that the idea of cooperation between university and industry is not a new one. Back in 1930s, Marshall wrote: "A small group of British 
scientists have made revolutionary discoveries in science; but the main fruits of their work were taken by companies from Germany, where industry and science are in close contact with one another" (Marshall 1923, under Ješić, 2015, p.29). There is nothing new in these requirements, so maybe this is where the greatest question lies - why is this so? Why a company that already knows the importance of cooperation between university and industry does not work on continuous improvement of this relationship? But what are the possibilities for cooperation? In societies where there is awareness that education and knowledge are public goods, cooperation between university and industry is strong, with, of course, the support of the state. Contrary to such societies, there are societies in which education and knowledge are seen as something unrewarding. There is no partnership between students and employers, or between university and industry. If there are such cases, they are referred to as examples of good practice or enthusiastic endeavors. Such ventures appear periodically, but not more than that. This is the type of society to which we belong, when it comes to cooperation of university and industry.

The benefits of a partnership of university and industry are multiple and include:

- Development of mutual trust between universities and partners from the business sector

- Improvement of scientific research

- Improving the process of teaching

- Improving student practice

- Identification of potential clients or partners for future research

- Attracting, retaining and motivating high-quality scientists interested in entrepreneurship

- Promotion of socio-economic importance of scientific and research projects.

It is imperative that local governments and institutions and state authorities develop cooperation with business, financial, and other organizations. As in striving to catch up with universities in the region and the world we are still passing through the structural reforms of education and harmonization with international documents, we should not neglect the basic global initiative, i.e. focus on the principles of social responsibility of higher education.

It is especially important to note that Serbia needs a strategy of economic development that will, in line with the development of society, be based on knowledge. "It means abandoning the current development strategy based on ongoing industrialization and the extensive use of energy and raw materials, inefficient investment in physical capital and the use of cheap labor of low- and medium-level qualifications, as well as the abandonment of the current social and institutional system which cannot solve development problems in the context of new technology related to economic growth, structural change, employment, standard of living and environmental protection" (Bošnjak, 2005, p.37).

\section{Conclusion}

Carried by the spirit of time, universities got some new roles. Their primary role of transmission of knowledge has not disappeared, but they got new ones. Higher education institutions have expanded their activities with research, especially 
through collaboration with industry. There are many aspects of this cooperation, ranging from students' practice, business incubators, joint research projects, to technology parks.

In an effort to provide a more favorable social environment for economic or social development, many countries gave a central role to universities, because they are a productive combination of science and practice. Science is the national priority of each country, and the cooperation of science and economy is a necessary condition for economic and business development of each country, including ours. This is the imperative of time. The sooner we realize this as a priority and the need of society, the more meaningful it will be for society itself.

Finally, we can conclude with one question, but not wanting to end up with this subject. On the contrary, a new debate should be opened, about what we are doing, or, better, what we have done with our forest wealth, vegetable and fruit farming, agriculture, pasture, tourism, geographical position, and, of course, with our intellectual capital?

\section{References}

Bilandžija G. (2010). Obrazovna tehnologija kao nužnost savremenog obrazovnog procesa TIO2010, Čačak, str. 238-244.

Bošnjak, M. (2005). Koncepcija razvoja inovativne privrede $i$ društva u republici Srbiji-Tehnologija, kultura i razvoj.Beograd: Institit Mihajlo Pupin i Centar za istraživanje razvoja nauke i tehnologije. 30-47.

Branković, J. (2012). Društvene promene, Bolonjski proces i treća misija Univerziteta u Srbiji. Teme, 36(3), 1157-1172.

Branković, D. (2014). Humanistički usmjereno vaspitanje i vrjednosne orjentacije mladih - Zbornik rezimea sa Međunarodne naučne konferencije Uloga obrazovanja i vaspitanja u razvijanju humanističkih, interkulturalnih i nacionalnih vrednosti. Filozofski fakultet Univerziteta u Prištini, Kosovska Mitrovica i Srpska akademija obrazovanja. str.19.

Gajić, O., Lungulov, B. (2012). Kompetencije za učenje tokom života: nužni ishodi visokog obrazovanja. Trendovi razvoja: Internacionalizacija univerziteta.

Ješić, J. (2015). Model četvorostruke spirale (QUADRUPLE HELIX MODEL) kao osnova nacionalnog inovacionog sistema, doktorska disertacija, Fakultet poslovne ekonomije, Univerzitet EDUCONS, Novi Sad, Srbija. (Available at: http://nardus.mpn.gov.rs/handle/123456789/5310).

World Bank Data, Gross Domestic Product (per capita) (Available at: http://www. tradingeconomics.com/serbia/gdp-per-capita).

Milanović, N., Žarlić, Joksimović, N., Benković, S., Milosavljević, M. (2014). Savremeni modeli transfera znanja univerziteta ka poslovnom svetu - Trendovi razvoja: razvojni potencijal visokog obrazovanja. 
Milošević, B. (2004). Naučno-obrazovne $i$ privredne organizacije u uslovima „glokalizacije“:Primeri uspešnog regionalnog „umrežavanja“ - Uloga Univerziteta u procesima saradnje i integracije privrede i društva na području Evrobalkana (Niš-Skoplje-Sofija). Zbornik diskusija sa okruglog stola. Filozofski fakultet Univerziteta u Nišu, Institut za sociologiju. Niš, str.45-50.

Nikić, V. Mostovi saradnje Univerziteta u Novom Sadu i privrede - primeri dobre prakse (Available at: http://www.finhed.org/media/files/Mostovi\%20 saradnje $\% 20$ Univerziteta $\% 20 \mathrm{u} \% 20$ Novom $\% 20$ Sadu $\% 20 \mathrm{i} \% 20$ privrede $\% 20$ -\%20Vladimir\%20Nikic.pdf.).

Penezić, N. D., Anđelić, G., Ješić, J., Andrejević-Panić, A., Vukadinović, S. (2015). Makroekonomski ambijent za razvoj Quadruple Helix modela regionalne konkurentnosti AP Vojvodine. Poslovna ekonomija, 9(2), 45-62.

Polovina, A., Mijušković, Lj., Kikinđanin, Lj., Milić, B. (2011). Učenje tokom života:nove mogućnosti saradnje Univerziteta i privrede, XVII Skup Trendovi razvoja : "Evropa 2020: društvo zasnovana na znanju". Kopaonik, Srbija.

Spasojević, D., Kleut, J., (2012). Društvene promene, bolonjski proces i treća misija univerziteta u Srbiji. Teme-Časopis za Društvene Nauke, (03), 1157-1172.

Štrbac, L. (2014). O nezaposlenosti. Nova srpska politička misao (Available at: http:// www.nspm.rs/ekonomska-politika/o-nezaposlenosti.html

Education Development Strategy by 2020 (http://www.kg.ac.rs/strategija obrazovanja_do_2020.).

Ministry of Finance - Public Debt Administration. Public Debt Stock and Structure - October 2016. p. 3 (Available at: http://www.javnidug.gov.rs/upload/Web site debt repor)

National Bank of Serbia. Report on Inflation - November 2016 (Available at: https:// www.nbs.rs/system/galleries/download/pdf_ioi/ioi_11_2016.pdf).

Social Inclusion and Povertly Reduction Unit. Available at http://socijalnoukljucivanje. gov.rs/rs/srbija-neznatno-napredovala-po-konkurentnosti/.

Statistical Office of the Republic of Serbia. Current indicators - unemployment data. (Available at: http://webrzs.stat.gov.rs/WebSite/Public/ PageView. aspx?pKey=2\). 